\title{
PEMANFAATAN GOOGLE MAPS API UNTUK VISUALISASI DATA BASE TRANSCEIVER STATION
}

\author{
Septia Rani \\ Jurusan Teknik Informatika, Fakultas Teknologi Industri, Universitas Islam Indonesia \\ Jalan Kaliurang Km.14,5 Sleman, Yogyakarta 55184 \\ Email :septia.rani@uii.ac.id
}

\begin{abstract}
This paper discusses the use of the Google Maps API to perform data visualization for Base Transceiver Station (BTS) data. BTS are typically used by telecommunications companies to facilitate wireless communication between communication devices with the network operator. Each BTS has important information such as it's location, it's transaction traffic, as well as information about revenue. With the implementation of BTS data visualization using the Google Maps API, key information owned by each BTS can be presented more attractive and also easier to understand. BTS data visualization supports decision-making processes related to company policies such as marketing strategy in order to increase the revenue of the company.
\end{abstract}

Keywords : Google Maps, Data Visualization, Base Transceiver Station.

\section{PENDAhUluan}

Teknologi internet yang saat ini berkembang pesat telah memberikan kemudahan bagi pengguna dalam mendapatkan informasi. Dengan memanfaatkan internet, kita bisa mengakses dan menemukan banyak informasi di seluruh dunia dengan cepat dan mudah. Kehadiran internet dan juga adanya kebutuhan akan informasi telah mendorong munculnya banyak sistem informasi, termasuk sistem informasi yang menggunakan peta geografis.

Sistem informasi geografis adalah sistem berbasis komputer yang digunakan untuk memasukkan, menyimpan, mengelola, menganalisis, dan mengaktifkan kembali data yang mempunyai referensi keruangan untuk berbagai tujuan yang berkaitan dengan pemetaan dan perencanaan (Burrough, 1986). Teknologi sistem informasi geografis dapat mengintegrasikan antara basisdata dengan berbagai keuntungan analisis geografis yang disajikan dalam bentuk peta. Sistem informasi geografis (SIG) telah diaplikasikan untuk berbagai keperluan, diantaranya: SIG dalam bidang kelautan dan perikanan (Zainuddin, 2006), SIG untuk menentukan daerah prioritas rehabilitasi (Narulita dkk., 2008), SIG untuk pemantauan posisi kendaraan (Hanifah dkk.,
2010), dan SIG untuk mengetahui lokasi industri (Setiaji, 2012).

Google Maps merupakan salah satu layanan yang menyediakan peta online dan citra satelit. Layanan yang disediakan oleh Google ini cukup interaktif dan dapat dimanfaatkan oleh developer web yang ingin mengembangkan sebuah sistem informasi geografis. Beberapa aplikasi yang pernah dikembangkan dengan memanfaatkan Google Maps diantaranya: aplikasi peta kampus (Ichtiara, 2008), SIG untuk pemetaan pariwisata (Swastikayana, 2011), dan aplikasi untuk sistem informasi pariwisata (Purnomo, 2015).

Google Maps memiliki banyak fitur, diantaranya yaitu pencarian (search) dan integrasi bisnis. Fitur - fitur yang dimiliki oleh Google Maps ini dapat dimanfaatkan oleh suatu perusahaan atau institusi untuk mengetahui persebaran aset yang dimiliki.

Pada makalah ini, penulis memanfaatkan Google Maps API untuk melakukan visualisasi data Base Transceiver Station (BTS) yang dimiliki oleh perusahaan telekomunikasi XYZ. Keberadaan BTS bagi masyarakat sangat penting karena perangkat tersebut dapat mengirimkan dan menerima sinyal dari perangkat mobile seperti telepon seluler, sehingga memungkinkan terjadinya komunikasi nirkabel antara piranti komunikasi 
dengan jaringan operator. Tujuan dari implementasi ini antara lain agar suatu perusahaan telekomunikasi dapat mengetahui letak aset BTS yang dimiliki beserta informasi yang tersimpan di setiap BTS.

Pembahasan pada makalah ini disusun sebagai berikut. Bagian 2 menjelaskan tentang Google Maps API. Bagian 3 mendeskripsikan implementasi yang dilakukan. Terakhir, kesimpulan dari makalah ini dijelaskan di bagian 4 .

\section{GOOGLE MAPS API}

Google Maps merupakan suatu layanan internet gratis yang dikeluarkan oleh Google Inc. dengan menyediakan teknologi pemetaan canggih yang dapat menampilkan peta suatu tempat di dunia. Fitur - fitur yang disediakan oleh Google Maps diantaranya sebagai berikut

a. Foto Satelit

Dengan fitur foto satelit ini, pengguna Google Maps dapat melihat gambar yang sama sesuai dengan kenyataan yang sebenarnya.

b. Hasil Pencarian dan Integrasi Bisnis

Fitur ini mempermudah pengguna dalam mencari suatu tempat yang ingin dikunjungi. Tempat yang dicari dapat berupa tempat wisata, tempat penginapan, tempat perbelanjaan, dan sarana umum lainnya.

c. Draggable Maps

Fitur ini memungkinkan peta yang ditampilkan dapat digeser dengan menggunakan bantuan mouse.

d. Zooming

Fitur ini memungkinkan pengguna untuk melihat peta secara lengkap dan detail dengan cara zooming (memperbesar) pada bagian peta yang diinginkan.

e. Terrains Maps

Fitur ini menyediakan informasi mengenai peta fisik atau peta topografi yang umumnya disediakan oleh buku peta atlas. Contohnya seperti informasi lokasi gunung berapi aktif di pulau Sumatera.

\section{f. Street View}

Dengan fitur ini pengguna dapat mengecek situasi jalan di tempat tertentu, misalnya mengecek situasi jalan di depan toko es krim favorit.

g. Petunjuk Arah Berkendara

Google Maps juga menyediakan fitur yang memberikan petunjuk arah dalam berkendara menuju suatu tempat. Google Maps dapat mendeteksi keberadaan pengguna dan meminta pengguna untuk memasukkan tempat tujuan yang diinginkan. Dengan kedua informasi tersebut maka Google Maps akan memberikan informasi jalan yang harus dilalui untuk menuju ke tempat tujuan.

Penggunaan Google Maps memiliki kelebihan, antara lain sebagai berikut :

a. Menampilkan peta jalan sesuai dengan keadaan nyata.

b. Tampilan peta dapat diubah sesuai dengan tampilan aslinya menggunakan fitur satelit.

c. Konten data yang ditambahkan ke peta akan disimpan di sisi server, bukan di sisi klien, sehingga data yang dimiliki menjadi lebih aman.

Google Maps API (Application Programming Interfaces) memungkinkan developer untuk mengkustomisasi peta dan informasi yang ditampilkan pada peta. Dengan API ini, developer dapat menambahkan Google Maps di halaman web milik sendiri. API menyediakan sejumlah utilitas/fungsi yang dapat digunakan untuk memanipulasi peta dan menambahkan konten ke dalam peta, sehingga memungkinkan developer untuk membuat aplikasi peta yang interaktif.

Berikut ini akan dijelaskan beberapa fungsi Google Maps Javascript API yang diimplementasikan pada makalah ini.

a. Map Sederhana

Peta akan ditampilkan sesuai dengan input yang ada di dalam script. Berikut ini script untuk menampilkan map sederhana : 


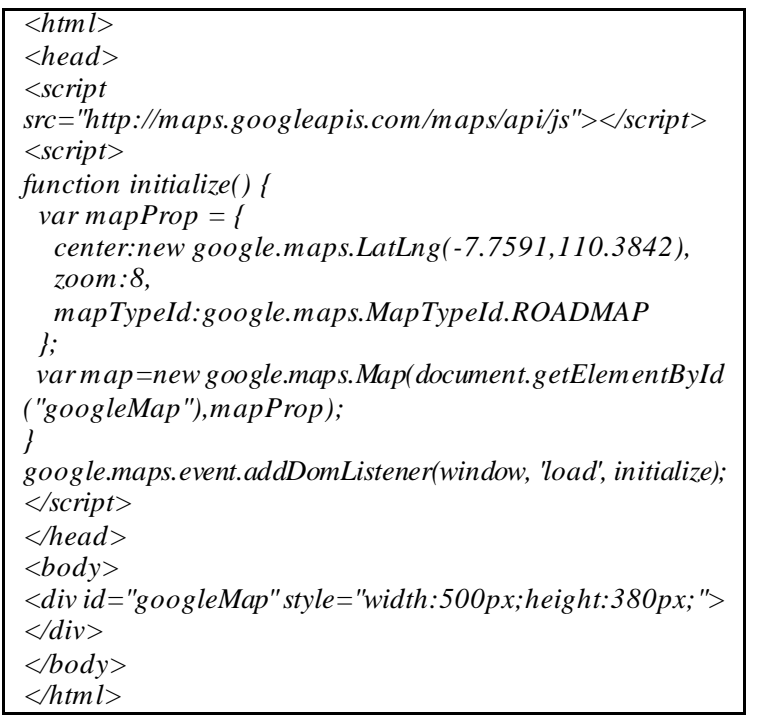

Output tampilan dari map sederhana dapat dilihat pada Gambar 1. Gambar peta yang tampil akan berpusat di koordinat latitude dan longitude sesuai dengan yang dituliskan pada kode program.

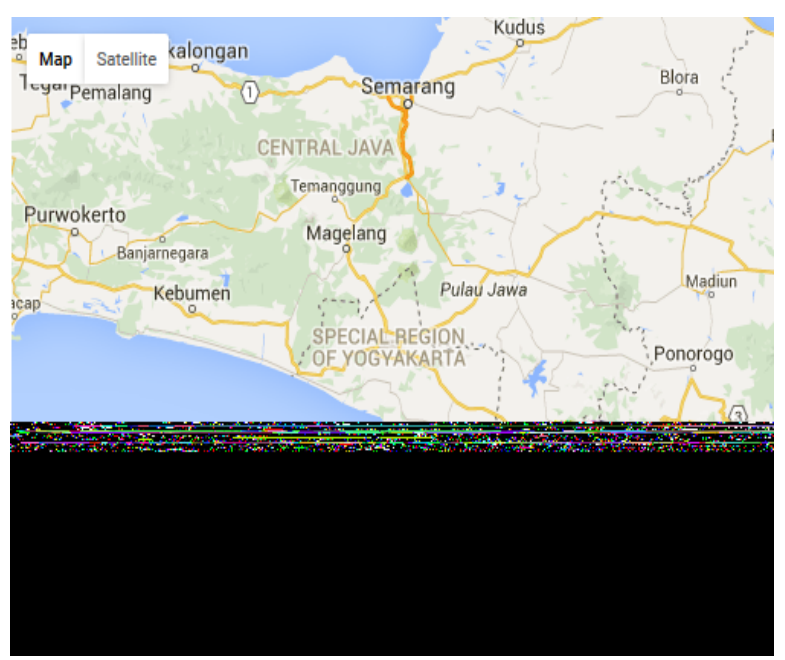

Gambar. 1 Contoh Peta Pada Google Maps.

b. Polyline Simple

Dengan menggunakan polyline simple, dapat dibuat garis antar titik pada peta. Garis dapat digunakan sebagai penanda dalam peta. Berikut ini contoh script untuk menampilkan polyline simple.

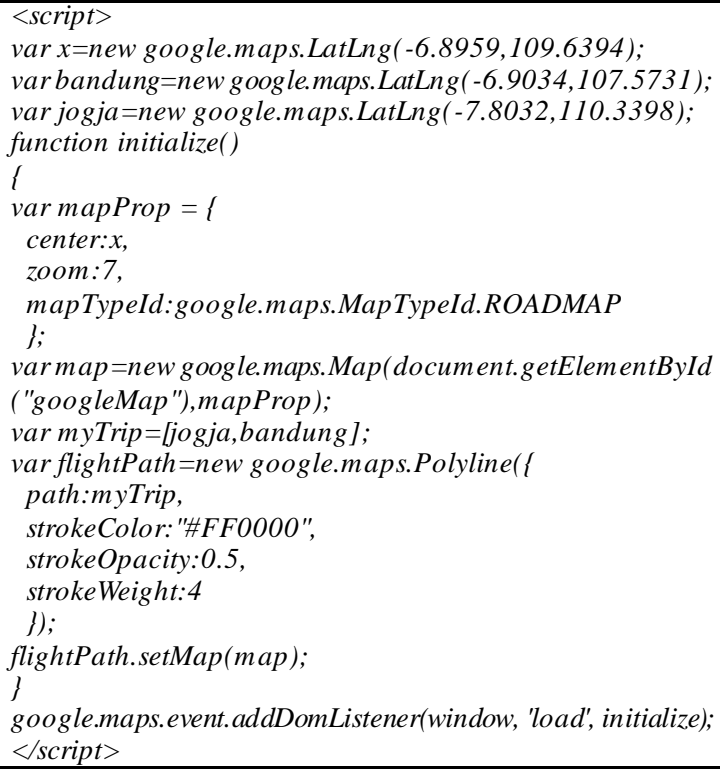

Output tampilan dari penggunaan polyline simple dapat dilihat pada Gambar 2. Pada contoh tersebut dibuat garis yang menghubungkan antara kota Bandung dengan kota Yogyakarta.

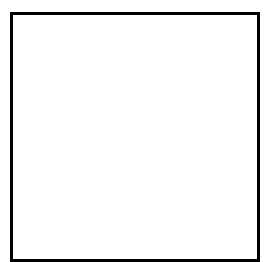

Gambar. 2 Polyline Simple pada Google Maps.

\section{c. Polygon Simple}

Polygon merupakan pengembangan dari polyline. Polygon dapat digunakan sebagai tanda area suatu tempat. Berikut ini contoh script untuk menampilkan polygon simple. 


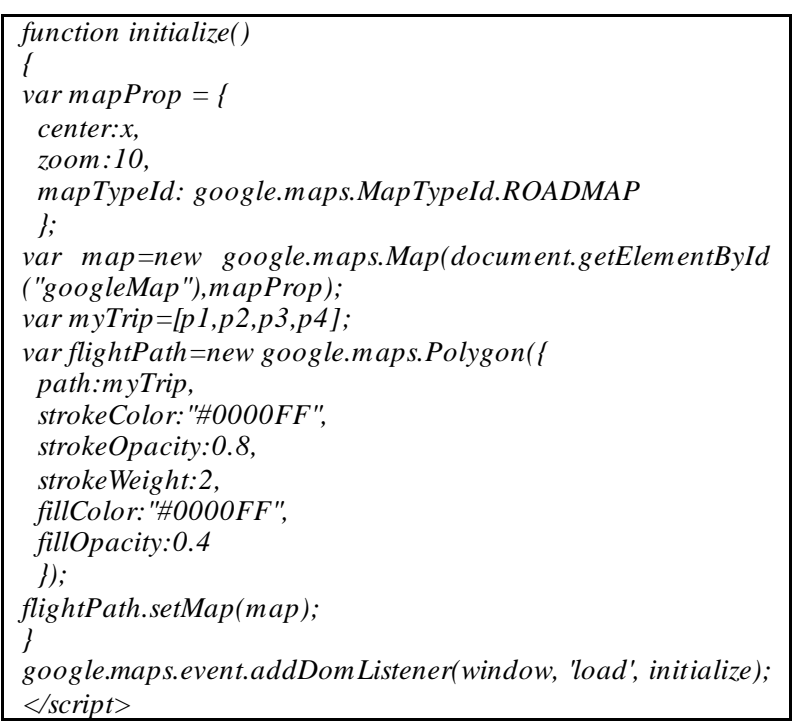

Output tampilan dari penggunaan polygon simple dapat dilihat pada gambar 3 .

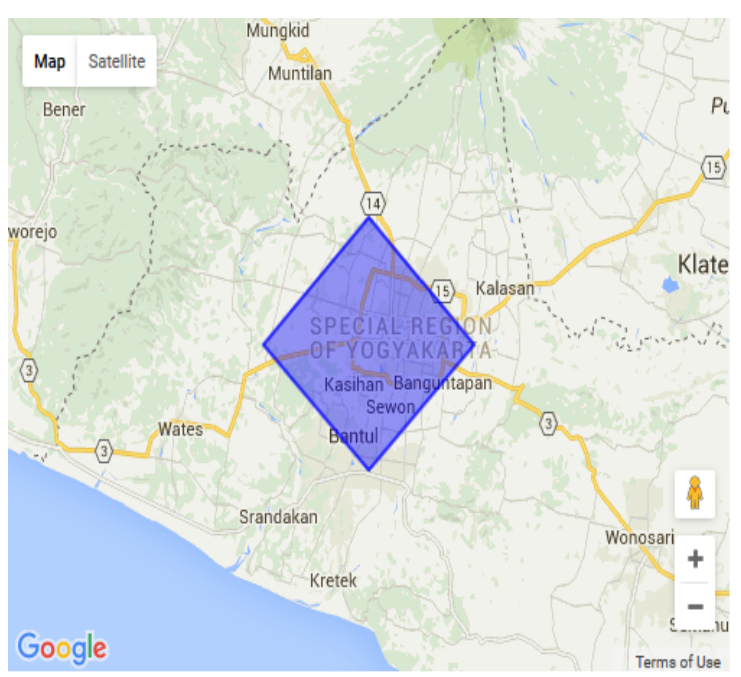

Gambar. 3 Polygon Simple pada Google Maps.

d. Info Window

Info window digunakan untuk memberikan informasi terhadap suatu titik yang terdapat pada peta. Dengan adanya info window, pengguna dapat mengetahui keterangan mengenai titik tersebut. Berikut ini contoh script untuk menampilkan info window.

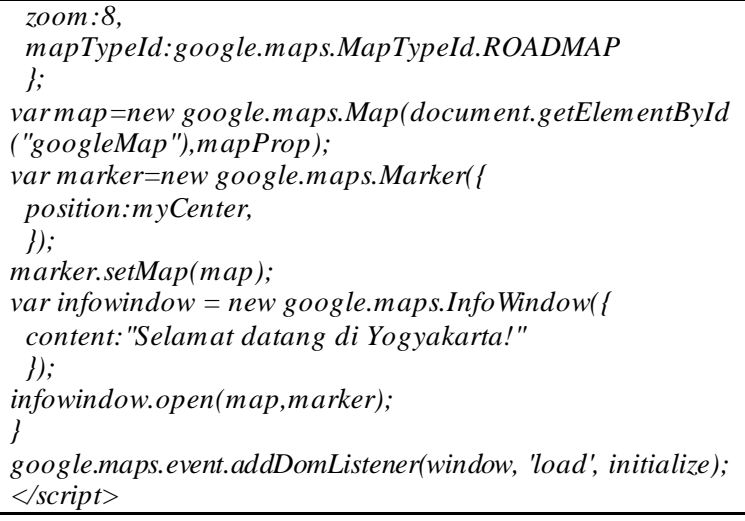

Output tampilan dari penggunaan info window dapat dilihat pada gambar 4.

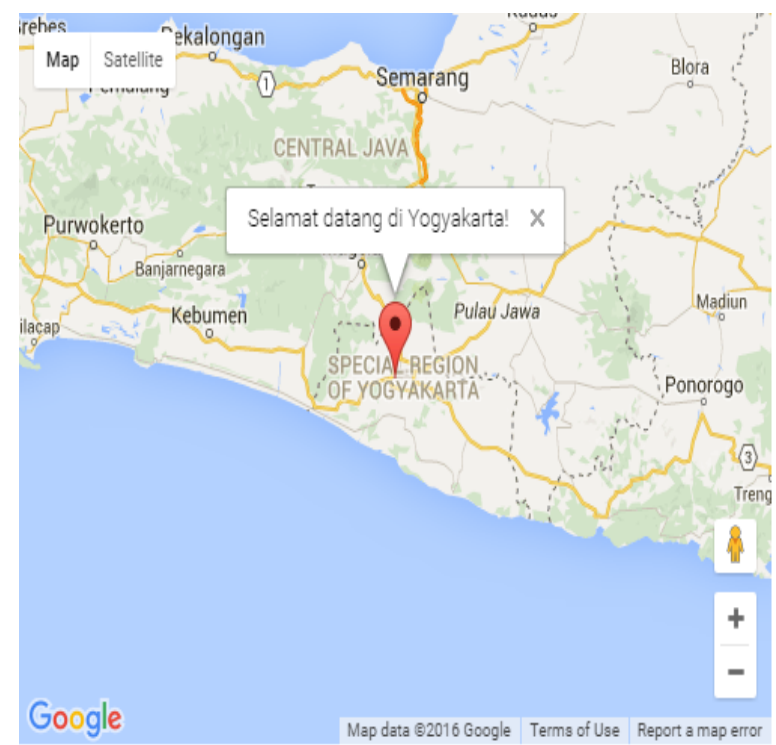

Gambar.4 Info Window pada Google Maps.

e. Event Closure

Event closure ditunjukkan dengan mengklik suatu titik pada peta yang kemudian akan keluar info window sebagai keterangan pada titik yang ditandai tersebut. Berikut ini contoh script untuk event closure.

〈script $>$
varmyCenter $=$ new google.maps.LatLng (-7.8032,110.3398);
function initialize( $)$
I
var mapProp $=\{$
center:myCenter,




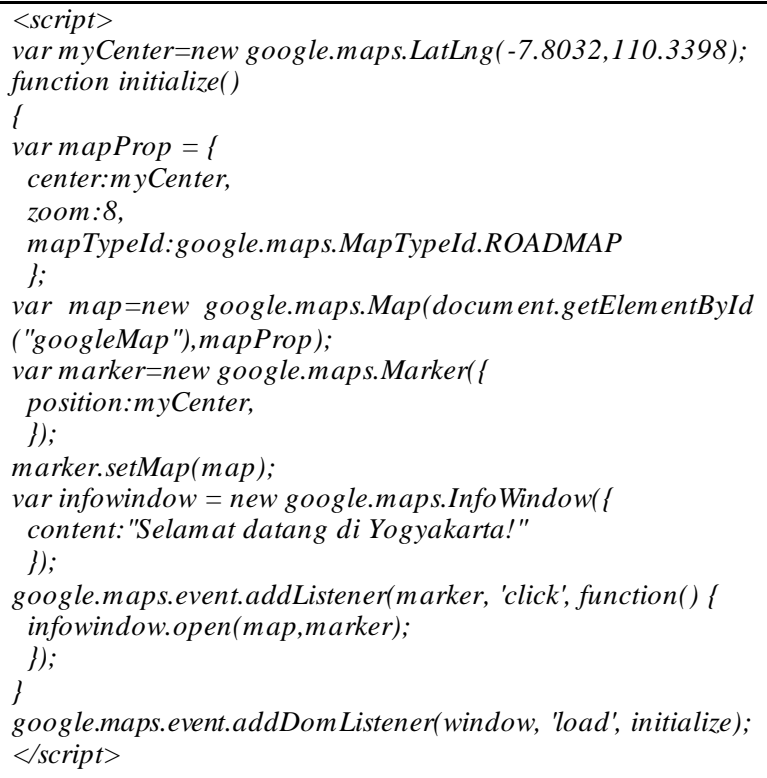

Output tampilan dari penggunaan event closure sama seperti yang terlihat pada gambar 4. Perbedaannya adalah info window baru akan muncul setelah pengguna mengklik penanda (marker) pada peta.

\section{IMPLEMENTASI}

Base Transceiver Station (BTS) merupakan pemancar sinyal, yang mana untuk setiap BTS biasanya terdiri atas beberapa cell yang memancarkan jenis sinyal yang berbeda (seperti sinyal GSM, sinyal 3G, dll). Pada makalah ini, sebagai contoh kasus maka akan dibuat sebuah aplikasi pelaporan data BTS untuk perusahaan telekomunikasi XYZ. Aplikasi yang dibuat bertujuan untuk memberikan visualisasi mengenai letak BTS -
BTS yang dimiliki oleh perusahaan tersebut dan dibatasi untuk wilayah tertentu (dalam implementasi kali ini dibatasi hanya untuk wilayah Provinsi Jawa Tengah dan Daerah Istimewa Yogyakarta).

Langkah - langkah yang dilakukan untuk implementasi sistem adalah sebagai berikut :

a. Membuat desain user interface.

b. Membuat fungsi untuk meng-generate query berdasarkan data-data pada form yang telah diisi oleh pengguna.

c. Membuat mekanisme untuk parsing datadata cell hasil query dari file PHP ke file Javascript. Mekanisme parsing ini menggunakan XML.

d. Membuat fungi - fungsi drawing menggunakan Javascript untuk menampilkan visualisasi cell di dalam Google Maps. Visualisasi cell menggunakan bentuk elips dan bentuk kerucut.

Tampilan dari aplikasi yang telah dibuat dapat dilihat pada gambar 5 . 


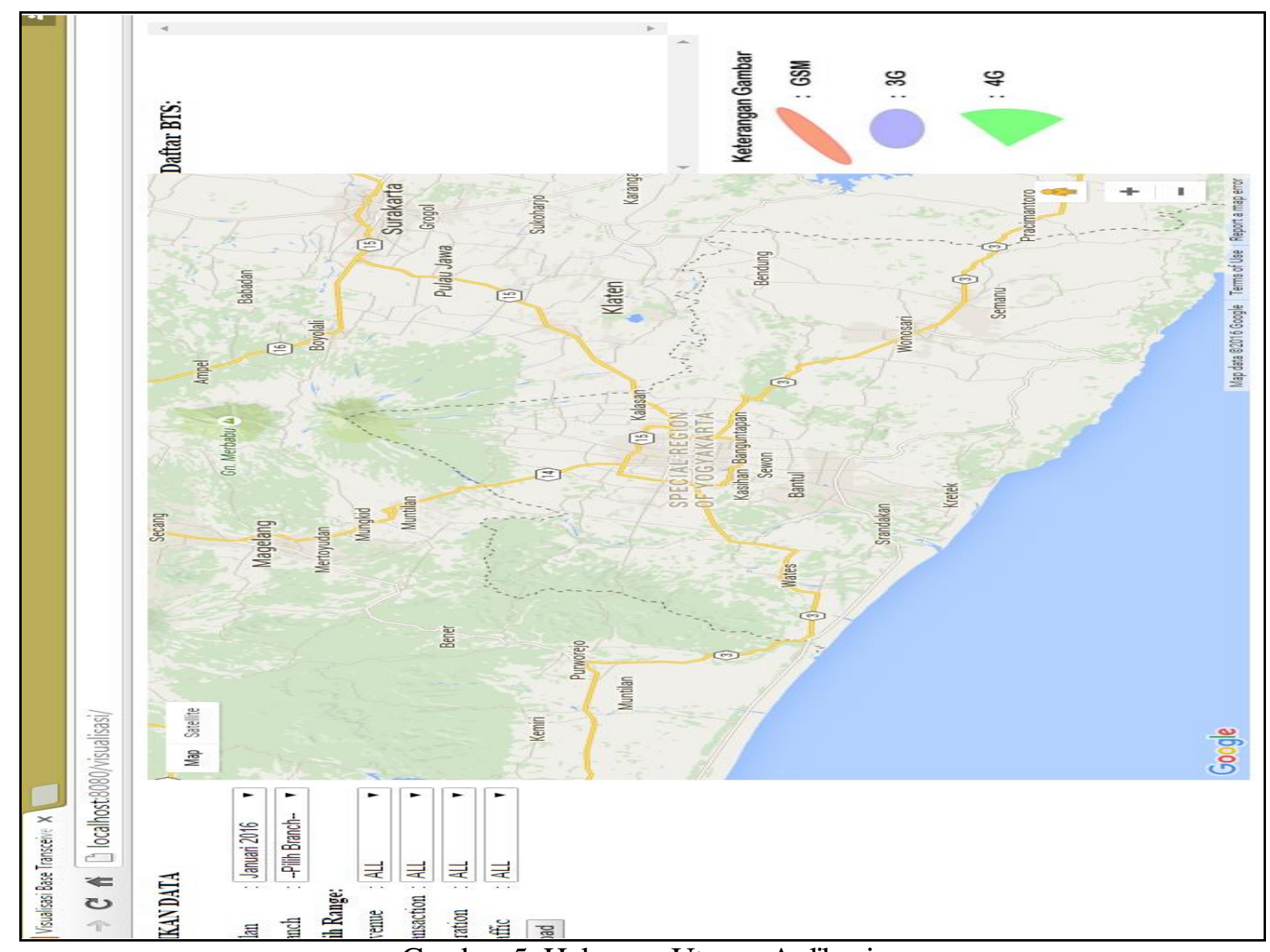

Gambar.5 Halaman Utama Aplikasi.

Pada saat pertama kali mengakses aplikasi, pengguna akan diminta untuk mengisikan pilihan data. Pilihan data yang harus diisi diantaranya pilihan "bulan", "branch", dan pilihan "range" (revenue, transaction, duration, traffic). Di sebelah kanan form isian ditampilkan gambar peta wilayah Jawa Tengah dan Daerah Istimewa Yogyakarta (Jateng - DIY) yang berpusat di kota Yogyakarta. Peta tersebut di-import dari layanan Google Maps. Selanjutnya di sebelah kanan peta terdapat keterangan gambar dan sebuah tabel yang akan berisikan daftar nama site BTS yang sesuai dengan pilihan (query) yang dimasukkan oleh pengguna.
Setelah pengguna mengisikan pilihan di sebelah kiri dan mengklik tombol "load", maka sistem akan segera memproses permintaan dari pengguna. Permintaan ini akan ditransformasikan menjadi sebuah query untuk mendapatkan cell - cell di basisdata yang memenuhi kriteria permintaan dari pengguna. Di browser pengguna akan ditampilkan alert yang berisi informasi mengenai banyaknya cell yang memenuhi kriteria yang sudah diisikan tadi. Pada contoh gambar 6, terdapat sebanyak 337 cell yang memenuhi kriteria sehingga akan digambarkan cell - cell tersebut pada peta. 
Setelah proses drawing (menggambarkan cell - cell di peta) selesai, di peta akan muncul gambar bentuk - bentuk elips dan kerucut yang sangat kecil, seperti terlihat pada gambar 7 .

\begin{tabular}{|c|c|c|c|c|c|}
\hline \multicolumn{6}{|c|}{ 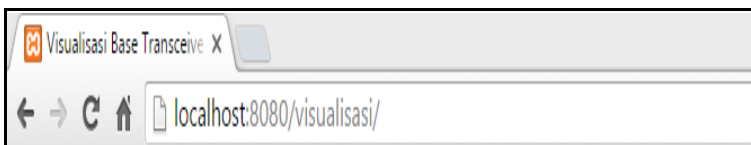 } \\
\hline \multicolumn{2}{|c|}{$\begin{array}{l}\text { Loading : } 11 \% \text { ||||||||| } \\
\text { ISIKANDATA }\end{array}$} & \multirow{6}{*}{\multicolumn{2}{|c|}{$\begin{array}{l}\text { localhost:8080 says: } \\
\text { Ada sebanyak:337 cell } \\
\square \text { Prevent this page from creating adoditional dialoogs. }\end{array}$}} & \multirow{6}{*}{\multicolumn{2}{|c|}{ OK }} \\
\hline Bulan & Januari 2016 & & & & \\
\hline Branch : & Semarang & & & & \\
\hline Pillih Range: & & & & & \\
\hline Revenlle & 50-100 juta & & & & \\
\hline Transaction: & 0.1 juta & & & & \\
\hline Duration & 0.30 juta detik & ' & & & \\
\hline Traffic & 0.30 ribu & ' & & & \\
\hline
\end{tabular}

Gambar. 6 Alert Banyaknya Cell.
Masing - masing gambar merepresentasikan sebuah cell. Gambar - gambar tersebut dibuat berbeda untuk membedakan jenis band dari setiap cell, yaitu apakah GSM, 3G ataukah 4G. Tabel daftar nama site BTS juga telah berisi link - link yang apabila diklik akan mengarahkan peta ke lokasi nama site BTS yang bersangkutan.

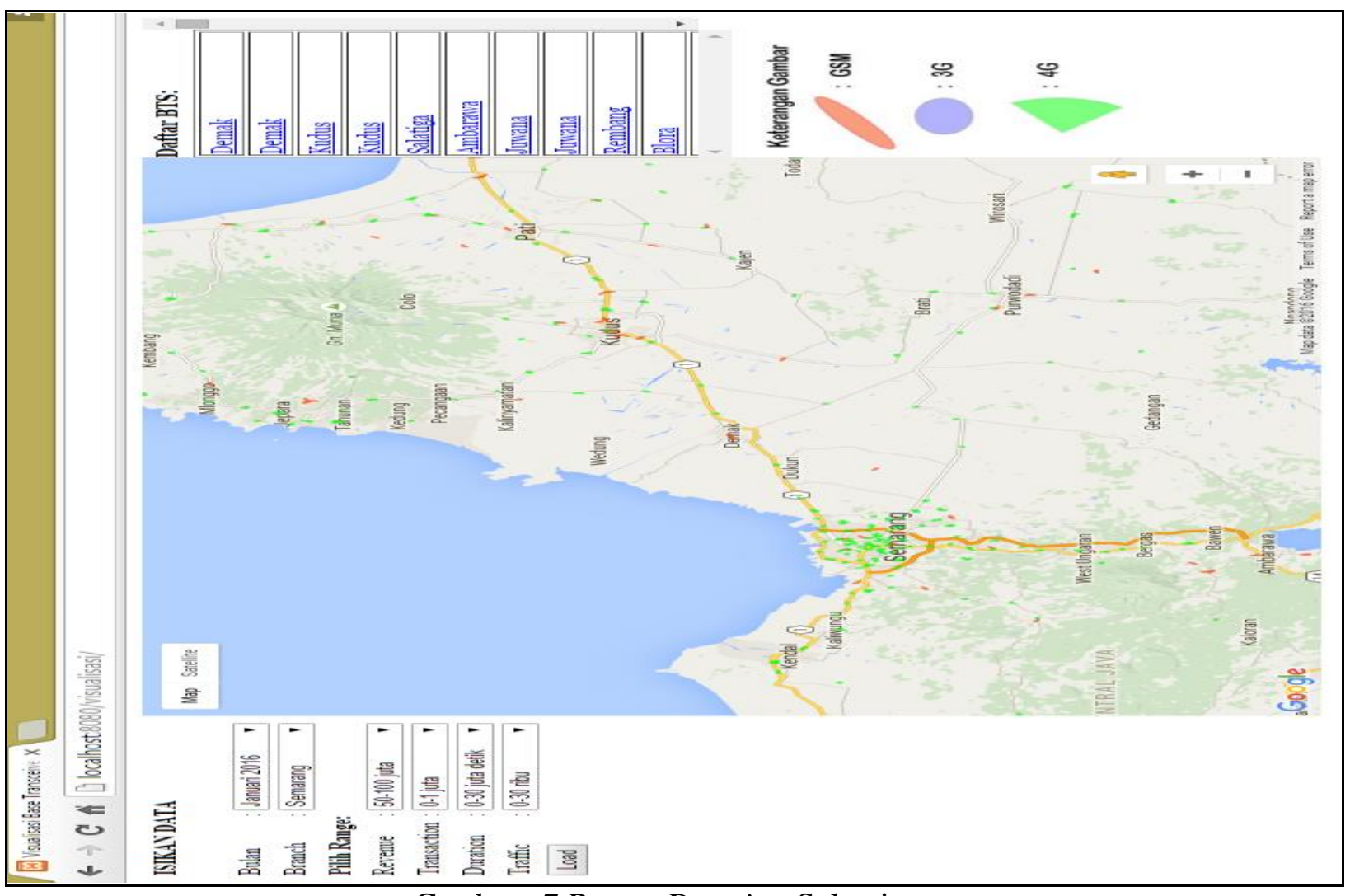

Gambar. 7 Proses Drawing Selesai. 
Sebagai contoh, pada saat pengguna mengklik tulisan link "Rembang", Google Maps akan bergeser secara otomatis ke lokasi dengan site name "Rembang". Tampilan gambarnya juga ikut diperbesar. Ilustrasi ini dapat dilihat pada Gambar 8. Setelah diperbesar, terlihat bahwa di site name "Rembang" terdapat dua buah cell yaitu sebuah cell GSM (direpresentasikan dengan gambar elips berwarna merah) yang mengarah ke barat daya dan sebuah cell $4 \mathrm{G}$ (direpresentasikan dengan gambar kerucut berwarna hijau) yang mengarah ke selatan.

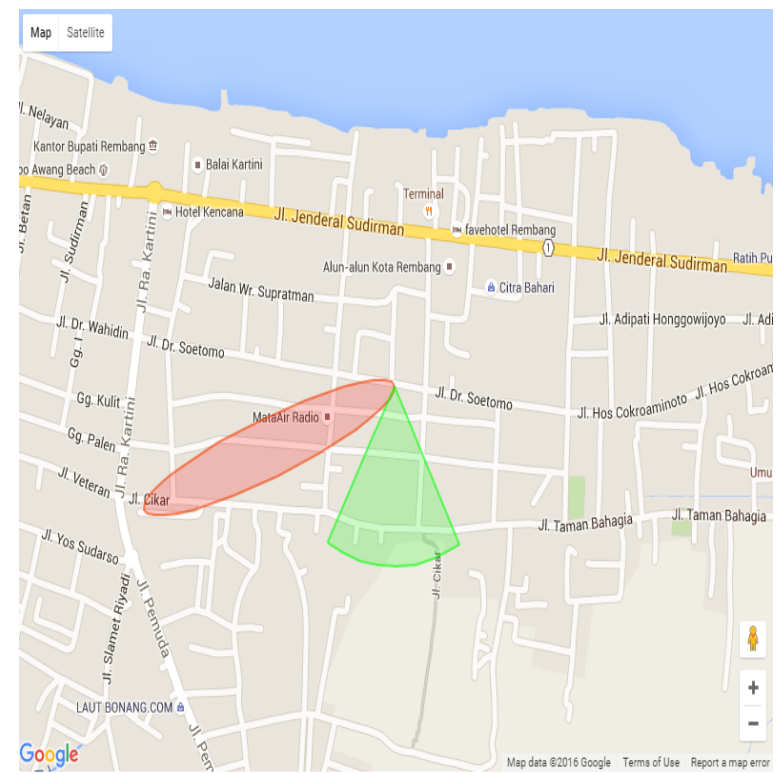

Gambar. 8 Peta Cell di Salah Satu Daerah.

Apabila pengguna mengklik suatu gambar cell tertentu yang tampil di Google Maps, akan muncul informasi lengkap mengenai cell tersebut di dalam Google Maps. Pada contoh Gambar 9, setelah pengguna mengklik pada area elips berwarna merah (cell GSM) maka akan muncul info window yang berisi informasi lengkap dari cell tersebut. Informasi yang ditampilkan meliputi informasi mengenai koordinat latitude dan longitude, arah cell, lokasi kecamatan dan kabupaten, besaran transaksi, durasi, dan rata-rata trafik, termasuk besaran revenue yang dihasilkan oleh cell tersebut.

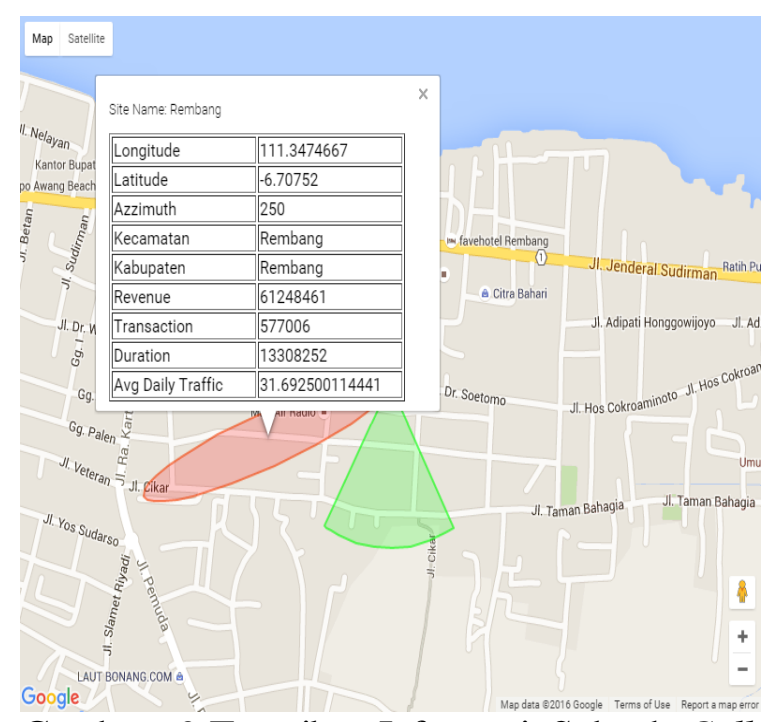

Gambar. 9 Tampilan Informasi Sebuah Cell.

Selain tampilan berupa gambar peta, di Google Maps sendiri telah menyediakan fitur untuk mengubah tampilan sesuai dengan citra satelit. Pada gambar 10, bisa dilihat bagaimana aplikasi yang dikembangkan dapat merepresentasikan lokasi - lokasi cell di lapangan. Citra satelit sangat berguna terutama untuk mengetahui keadaan nyata di lapangan, seperti informasi apakah BTS terletak di daerah yang padat pemukiman atau tidak. Informasi seperti ini sangat berguna untuk mengambil keputusan terutama untuk upaya pemasaran dan promosi produk / layanan.

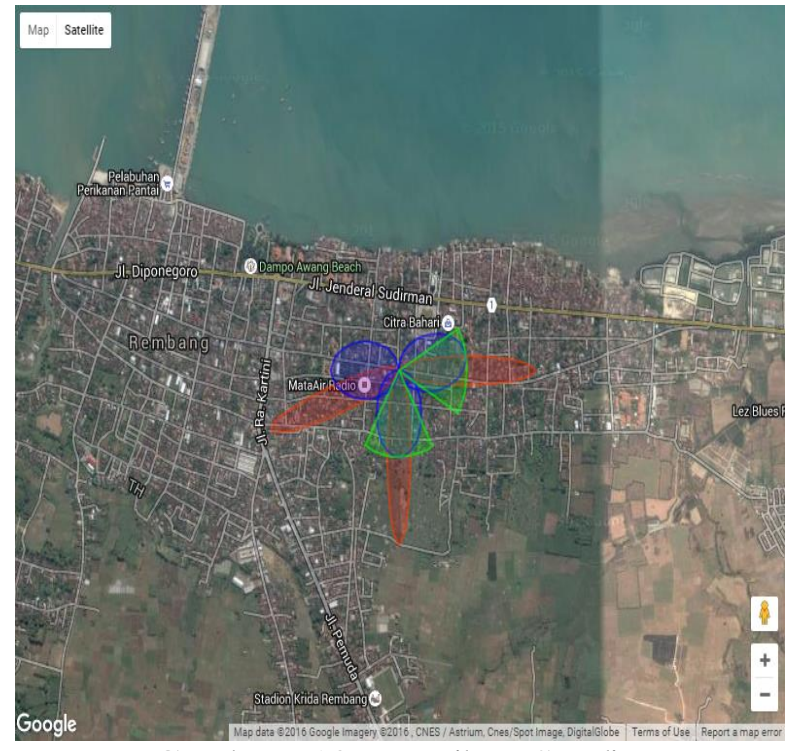

Gambar. 10 Tampilan Satelit. 
Setelah dikembangkannya aplikasi visualisasi data Base Transceiver Station dengan memanfaatkan Google Maps, ada beberapa keuntungan yang diperoleh, diantaranya adalah :

a. Aplikasi ini memberikan gambaran yang nyata mengenai lokasi serta bagaimana distribusi BTS-BTS.

b. Penyajian informasi sebuah cell (untuk keperluan reporting) menjadi lebih menarik dan informatif karena menyertakan gambar petanya.

c. Dengan melihat data persebaran BTS, aplikasi yang memanfaatkan Google Maps ini dapat membantu dalam hal pengadaan / pembangunan BTS baru.

d. Aplikasi akan sangat membantu dalam hal pengambilan kebijakan perusahaan seperti contohnya dalam hal marketing.

\section{KESIMPULAN}

Pemanfatan Google Maps API untuk visualisasi data Base Transceiver Station (BTS) membuat informasi - informasi penting yang dimiliki oleh BTS dapat disajikan dengan lebih menarik dan lebih mudah dipahami. Persebaran lokasi dari BTS menjadi lebih mudah untuk dipantau. Visualisasi data BTS ini juga mendukung proses pengambilan keputusan oleh perusahaan terkait kebijakan yang berkaitan dengan marketing dalam rangka meningkatkan revenue dari perusahaan.

Untuk kedepannya, aplikasi visualisasi data BTS dapat dikembangkan agar dapat diakses dengan menggunakan perangkat mobile seperti ponsel Android. Selain itu juga perlu ditambahkan menu penunjuk arah dari lokasi pengguna ke lokasi BTS sehingga akan memudahkan petugas apabila ingin melakukan peninjauan secara langsung ke lokasi BTS.

\section{DAFTAR PUSTAKA}

Burrough, P.A. Principles of Geographical Information Systems for Land Resources Assessment. Clarendon Press. Oxford. 1986.

Hanifah, R., Isnanto, R.R., dan Christyono, Y. Simulasi Sistem Informasi Geografis (SIG) Pemantauan Posisi Kendaraan Via SMS Gateway. TRANSMISI. 12 (2), 45-49. 2010.

Ichtiara, C. Implementasi Aplikasi Sistem Informasi Geografis Universitas Indonesia Berbasis Web dengan Menggunakan Google Maps API. Universitas Indonesia. Depok. 2008.

Narulita, I., Rahmat, A., dan Maria, R. Aplikasi Sistem Informasi Geografi untuk Menentukan Daerah Prioritas Rehabilitasi di Cekungan Bandung. Jurnal Riset Geologi dan Pertambangan. Jilid 18 No.1. 2335. 2008.

Purnomo, A.S. Implementasi Google Maps API dengan PHP dan MySQL (Kasus: Sistem Informasi Pariwisata). Jurnal Teknologi Industri. Vol.21. No.1. 1-6. 2015.

Setiaji, P. Sistem Informasi Geografis Industri di Kabupaten Kudus. Seminar Nasional Teknologi Informasi \& Komunikasi Terapan (Semantik). 2012.

Swastikayana, I.W.E. Sistem Informasi Geografis Berbasis Web untuk Pemetaan Pariwisata Kabupaten Gianyar. Universitas Pembangunan Nasional Veteran. Yogyakarta. 2011.

Zainuddin, M. Aplikasi Sistem Informasi Geografis dalam Penelitian Perikanan dan Kelautan. Lokakarya Agenda Penelitian. Selayar. 2006.

http://www.w3schools.com/googleapi/ diakses 7 Februari 2016. 